\title{
Intelligent Leadership Based on Catholic Perspective
}

\author{
Dankha Abdulmasih \\ Catholic University, Erbil, Iraq \\ Email: dankha.joola@cue.edu.krd
}

How to cite this paper: Abdulmasih, D. (2021). Intelligent Leadership Based on Catholic Perspective. Open Journal of Leadership, 10, 39-45.

https://doi.org/10.4236/ojl.2021.101003

Received: January 31, 2021

Accepted: March 22, 2021

Published: March 25, 2021

Copyright $\odot 2021$ by author(s) and Scientific Research Publishing Inc. This work is licensed under the Creative Commons Attribution International License (CC BY 4.0).

http://creativecommons.org/licenses/by/4.0/

\begin{abstract}
Leadership is essential for transformation, whether in the community or organization. Christian principles and teachings bring about different ethical principles that influence different aspects of life, including leadership. The catholic church in particular, has had a strong impact in leadership globally. This article describes the catholic perspective on intelligent leadership, emphasizing on the values that define intelligent leadership like dignity, justice and collaboration for a common good. The purpose of this paper is to define intelligent leadership and explore the relationship between leadership as a vocation in Catholics and employee-oriented leadership.
\end{abstract}

\section{Keywords}

Leadership, Intelligent Leadership, Catholic Leadership, Catholic Perspective

\section{Introduction}

Catholic teachings in a social perspective mostly focus on aspects like employers and employees, human work, and vocation. Leadership in the catholic perspective describes how human beings and their actions that are derived from faith, are taken and in the political, economic and social settings (Marek, 2015). From a catholic perspective, the church considers leadership as a calling and a charism. According to Eamon (2015), leadership is a gift from the Holy Spirit, to serve God and His people as they build the Body of Christ. Therefore, it is right to think about leadership and how these aspects affect individuals' intelligence in leadership (Schuttloffel, 2020). All these issues are common to leadership because a man's agreement with God's word calls for such roles in society (Schuttloffel, 2020). The Catholic teachings help people come to terms with God's word that calls for leaders to do according to God's will, participate in the 
works of creation, and encourage others to work towards the same goal (Bane, 2014). Therefore, leadership is a subject that has a high focus on Catholics.

People from the perspective of the Catholicism who seeks to hold the leadership are the subject of God's call, which helps them realize the roles and exposed them to some skills that can help to act intellectually (Marek, 2015). Catholic social teachings put regulations in place that call for every person to build the world by realizing their vocation. A vocation perspective demonstrating leadership leads others to follow God's word and act according to the word (Bane, 2014). Among the values that a leader should have included; respect for human rights and dignity, justice, and freedom. For one to get such principles, he/she must practice servant leadership.

Although research provides data on different types of leadership including transformational leadership (Korejan \& Shahbazi, 2016), and authentic leadership (Makhmoor, 2018), little is documented on the intelligent leadership based on the catholic perspective. There is a need to explore the different leadership aspects that lead to success according to the Catholic teachings. Therefore, this paper explores the elements that define an intelligent leader from the Catholic perspective.

\section{Intelligent Leadership in Catholic Context}

Intelligent leadership can be defined as the collaboration between leaders and their subordinates as they try to impact each other with an aim of achieving common goals effectively. These members share similar values and cultures that affect the outcomes (Sydanmaanlakka, 2003). Achieving Intelligent leadership should originate from the people's hearts side by side with their minds due to mutual relations and interactions but not due to orders and assignment of tasks. Intelligent leadership drives the subjects to honour directions and rules by breaking down personal interests barriers (Marek, 2015). Therefore, the necessary foundation of leadership dwells on motivating people to pursue organizational aims, the primary mission. Intelligent leaders performed the skills and abilities to frame organizational goals and present them to subordinates in an understandable and attractable manner (Bane, 2014). Therefore, the role of leadership, in this case, meets the primary goal of motivation. Leaders should also decide on the standards, sequence targets, and priorities and call for their implementation (McNeely, Duncan, \& Ree, 2017). However, getting people to utilize their potential in achieving these shared goals requires intelligent leaders with a good sense of mission.

Gardner \& Stough (2002) postulate that an intelligent leader does not take the law in his hand. He should not handle disputes with personal intentions. Some leaders utilize their authority and positions in exploiting, intimidating and manipulating their juniors. As they do this, they are very informed of the subjects' human rights. The bible condemns such leaders and advises them to be just to their employees. These leaders must be ready to defend their subjects and speak 
for them. Additionally, they must show fair judgement in their deals.

"Open your mouth for the mute, for the rights of all who are destitute.

Open your mouth, judge righteously, defend the rights of the poor and needy." (Proverbs 31: 8 - 9)

An intelligent leader understands the origin of various people and their respective challenges. If they do not have the intelligence to understand, they may victimize persons by diving into irrational judgement on them. The catholic teaching convicts such kind of leadership and treats it as poor leadership. Leadership calls for many sacrifices. There is a story of one shepherd who left a flock of 99 sheep but sacrificed to get one that had lost in the Bible (Mathew, 18: 12). The catholic perspective requires an intelligent leader to be ready for any consequences in their ruling styles and determine the best solutions. In Goleman's work, he encourages accountability and transparency in all fields (Goleman, 2001). It is only as such that all subjects shall know that their leaders are intelligent and uses their resources responsibly. In the Catholic perspective, an intelligent leader must encourage people to work in teams and embrace consultation. By so doing, people tend to work as a team and are always free to consult from each other. This is in line with the catholic teaching on the unity of believers found in Philippians 2: 2

"then make my joy complete by being like-minded, having the same love, being one in spirit and of one mind."

Encouraging people to work might require some skills that involve providing necessary assets and an environment. So propels realization of tasks; sharing enthusiasm with the staff while emphasizing goals; supporting subordinates to improve their self-esteem; encouraging employees to build good relationships themselves, which increases interactions. Implementation of innovative solutions and changes in any organization highly depends on leadership (Marek, 2015). Therefore, leaders necessity to act in a habit that demonstrates innovation through the initiation of new projects. Catholic leaders perceive these projects as an influential part of goals rather than form revenue. Such leaders believe that any contribution to society with a common goal has much more value than just financial profit 4 (Bane, 2014). Innovation and implementation of changes require collaboration between groups and individuals, and therefore, interpersonal relationship is essential for the realization of common goals.

\section{Leadership as a Vocation in Catholics}

There is no conventional approach to issuing a direction to people; motivational leaders differ from those with a vocation. The former assumes the ownership of everything such as the organization, relationship with people, marital and social status, and later lives with an understanding that God is the owner of everything and created people to live according to his purpose (Bane, 2014). God forms the center of Catholic leaders in their work, actions, decisions, and life. Intelligent 
leadership among Catholics requires one to understand that work is not only for material and earthly progress but also for building God's kingdom. All catholic leaders involve prayers in every duty they perform. Work is, therefore, perceived as a managed asset from God as exemplified by the master who distributed talents among his servants in Mathew 25: 14 - 27 and was to come back with interest (Marek, 2015).

Therefore, perceiving leadership as God's call should make people perform their creators' duties. A man has a word of God to make the world better. However, the primary goal should not only focus on personal development but also on driving others towards the same ideas and goals through the teaching of God's word (Marek, 2015). According to the Catholic faith, leadership must involve instructions and teachings from God's word, and all subjects must involve Godly traits in all their undertakings. The shape of Leaders is the framework that includes organizations working to become even better in the future (Bane, 2014). Intelligent leadership improves social status and results in the development of personal dignity through a feeling of excellence. However, in the Catholic framework of the leadership 5 for the people is about, facilitation, and development to become of high dignity through leaders' works.

Further to personal development, those who pursue leadership as a vocation essential utilize God's principles to help those subjected to them improve their businesses, work, and social relationship during their interactions (Dive, 2020). Catholic teachings on social aspects highlight some employers' values as demonstrating respect to people for their rights and human dignity. Work be taken as a way to salvation in the act of building the world (Schuttloffel, 2020). Therefore, leaders obligation coordinate with the subjects to build relationships that favour collaboration and goal-oriented motivation in achieving personal and social goals (Bane, 2014). Integrating the moral teachings from the catholic faith with leadership might result in more intelligent leaders.

On the same vein, Pope Francis drafts an encyclical letter (Laudato Si') 2015. in which he addresses the role of intelligent leadership on environmental concerns. In his letter, he postulates that environmental concerns must be a concern on intelligent leaders' minds. An intelligent leader ought to take care of his vicinity. He/she must mobilize resources and human power in a concerted effort geared towards environmental conservation. He cites examples of the initiative that different organizations have set out in line with environmental conservation. These powerful words by the Pope are in line with the biblical teachings on taking control over the whole earth as commanded by God in Genesis 2: 15 .

"The LORD God took the man and put him in the garden of Eden to work it and keep it."

\section{Employee-Oriented Leadership}

Catholic leadership principles require employees' treatment as subjects and not as objects, which directly implies human rights protection and respect for per- 
sonal dignity (McNeely, Duncan, \& Ree, 2017). The industrial revolution has resulted in changes in the economy. In addition to that, the decisive production factors have shifted from land and capital to people themselves. People reproduce their skills, knowledge, competencies, and satisfaction of each individual during the interaction. Therefore, people have many aspects that require dignity and respect (Dive, 2020). The right to life is a fundamental human right, and all other human rights draw on this fundamental right. Human life has meaning to personal dignity and cannot compare to any other value or goods (McNeely, Duncan, \& Ree, 2017). Therefore, catholic leaders understand the virtue of respect for human dignity as significant in building intelligent leadership. One can only demonstrate intelligent leadership if he/she can realize the social, emotional, and physical factors that might affect their subjects, such as employees in their productivity and goal attainment.

Catholic leaders tend to value work more than capital, which implies the role of servants. Leaders understand that intelligence comes with the word of God, and leaders must focus on instilling the knowledge about this word of God among believers (Marek, 2015). Demonstrating teamwork and participating in regular tasks motivates others to work and respect an organization's leadership or any workplace (Dive, 2020). Therefore, knowledge of the requirements of God's word concerning leadership must help people respond to work as a form of participating in God's creation, and this reveals the leadership among people.

Understanding the relationship between leadership as a vocation and employee-oriented leadership is important in intelligent leadership. Both aspects of leadership are important in influencing intelligent leadership. The vocational aspect of leadership influences how the leader will treat his employees. When a leader understands that leadership is for building God's Kingdom, they will treat their employees better.

\section{Collaborating in Management to Create Common Good}

Catholic teachings highly focus on the common good as one of the fundamental values of society. Therefore, catholic leaders should not strive to achieve personal interests but should ensure the common good for every community member (McNeely, Duncan, \& Ree, 2017). Intelligent leaders must focus on building prosperity among their subjects and helping them pursue their mission or organization and the community. Therefore, leaders must play a role in recognizing individuals with their abilities and hidden potentials to make them better members of the community (Schuttloffel, 2020). Catholic leaders participate in community development to improve the world around them and make everyone an enjoyable journey. It is only through such developments that leaders meet a co-worker's role from the word of God.

There was an international conference in which the Holy Father Francis wrote to all participants in line with this. The conference aimed to promote integral human prosperity. It took place in the Vatican's New Synod Hall from 23 to 24 
November 2017. In the letter, he urged all persons to embrace work. Moreover, he diverts and talks about leaders who fuel the politics of corruption. He urged that intelligent leadership must guard itself against the cancer of corruption (Apostolic Exhortation Evangelii Gaudium, 60). He goes further to condemn trade unionists who sign agreements with business groups but end up neglecting workers. According to the catholic perspectives, such trait undermines the good relationship among people. Additionally, it spoils lives and family ties. This point of view of the Catholic Church on intelligent leadership is in line with what is contained in the Holy Bible in Roman 8: 18 - 22.

"18 For I consider that the sufferings of this present time are not worth comparing with the glory that is to be revealed to us. 19 For the creation waits with eager longing for the revealing of the sons of God. 20 For the creation was subjected to futility, not willingly, but because of him who subjected it, in hope 21 that the creation itself will be set free from its bondage to corruption and obtain the freedom of the glory of the children of God. 22 For we know that 8 the whole creation has been groaning together in the pains of childbirth until now."

For a community or organization to meet a common goal, people must change their reasoning. People must not perceive the community's first-person view like "I" but see the picture of "We" in a community. Centesimus Annus 1991, suggests that human discipline involves working in collaboration to facilitate the creation of working communities (McNeely, Duncan, \& Ree, 2017). Intelligent leadership, therefore, involves industriousness, diligence, reliability, prudence in risks, and fidelity. Management leadership aligns with catholic leadership when it comes to building teams (Schuttloffel, 2020). In Management, teams are built through the participation of everyone in achieving a common goal and collaboration. Therefore, according to the catholic perspective of intelligent leadership, a leader should collaborate with others to bring about the desired goals.

\section{Findings}

From the above, there are different catholic perspectives concerning intelligent leadership, including core values such as respect for human dignity and human rights, and justice. These values are derived from biblical teachings that guide leadership. The Catholic church views leadership as a calling or charism whereby leadership is a gift to serve God and humanity, and not for personal gain. The Catholic perspective on intelligent leadership is that it involves treating employees equally and serving everyone, while collaborating with others for a common good.

\section{Conclusion}

Leadership is essential for transformation, whether in the community or organization. Catholic teaching on social values also highly emphasizes leadership's concept to lead others into the transformation of self and the world around 
them. Leaders should implement rules and regulations that reflect the biblical teachings and the word of God. Participation in Management and employee-oriented leadership can help motivate people to act in the form defined by God's word. Therefore, leadership not only focuses on individual growth but mostly on the development of others and the world around them. It takes a good understanding of a personal relationship with God and agreement with his word to meet the qualities that define intelligent leadership. Every challenge in leadership must have a biblical concept that helps one get a resolution. There is still a need for more researches in the area, to emphasize the different aspects of intelligent leadership that should be adopted for effective leadership.

\section{Conflicts of Interest}

The author declares no conflicts of interest regarding the publication of this paper.

\section{References}

Bane, M. J. (2014). Catholic Social Teachings, American Politics and Inequality. Journal of Catholic Social Thought, 11, 391-404. https://doi.org/10.5840/jcathsoc20141127

Cf. Apostolic Exhortation Evangelii Gaudium, 60.

Dive, B. (2020). Accountability and Leadership in the Catholic Church (2nd ed.). Cambridge: Cambridge Scholars Publishing.

Eamon, M. (2015). Leadership-A Catholic Perspective' Opening Address by Archbishop Eamon Martin to Annual Round Table Discussion at Marino Institute of Education. https://www.catholicbishops.ie/2015/03/03/leadership-a-catholic-perspective-archbisho p-eamon-martin-annual-round-table-discussion-marino-institute-of-education

Gardner, L., \& Stough, C. (2002). Examining the Relationship between Leadership and Emotional Intelligence in Senior-Level Managers. Leadership \& Organization Development Journal, 23, 68-79. https://doi.org/10.1108/01437730210419198

Goleman, D. (2001). Emotional Intelligence: Issues in Paradigm Building. In D. Goleman, \& C. Cherniss (Eds.), The Emotionally Intelligent Workplace: How to Select for, Measure, and Improve Emotional Intelligence in Individuals, Groups, and Organizations (pp. 13-26). San Francisco, CA: Jossey-Bass.

Korejan, M. M., \& Shahbazi, H. (2016). An Analysis of the Transformational Leadership Theory. Journal of Fundamental and Applied Sciences, 8, 452-461. https://doi.org/10.4314/jfas.v8i3s.192

Makhmoor, T. (2018). Authentic Leadership: Concept of Authenticity and Qualities of Authentic Leaders. Erişim tarihi, 29.

Marek, A. (2015). Leadership in Catholic Social Teaching. Annales. Etyka w Życiu Gospodarczym, 18, 1-13. https://doi.org/10.18778/1899-2226.18.4.02

McNeely, J. P., Duncan, P., \& Ree, M. J. (2017). GLOBE US Leadership Preferences versus Black American Catholics' Globe Leadership Preferences. The International Journal of Religion and Spirituality in Society, 7, 69-80. https://doi.org/10.18848/2154-8633/CGP/v07i03/69-80

Schuttloffel, M. J. (2020). International Explorations of Contemplative Leadership in Catholic Education. London: Routledge. https://doi.org/10.4324/9780367086886-1

Sydanmaanlakka, P. (2003). Intelligent Leadership and Leadership Competencies: Developing a Leadership Framework for Intelligent Organizations. 